\title{
Conflict between Freedom of Expression and Religion in India-A Case Study
}

\author{
Amit Singh \\ Centre for Social Studies, University of Coimbra, Colégio de S. Jerónimo Apartado 3087, 3000-995 Coimbra, \\ Portugal; amitsingh@ces.uc.pt
}

Received: 24 March 2018; Accepted: 27 June 2018; Published: 29 June 2018

\begin{abstract}
The tussle between freedom of expression and religious intolerance is intensely manifested in Indian society where the State, through censoring of books, movies and other forms of critical expression, victimizes writers, film directors, and academics in order to appease Hindu religious-nationalist and Muslim fundamentalist groups. Against this background, this study explores some of the perceptions of Hindu and Muslim graduate students on the conflict between freedom of expression and religious intolerance in India. Conceptually, the author approaches the tussle between freedom of expression and religion by applying a contextual approach of secular-multiculturalism. This study applies qualitative research methods; specifically in-depth interviews, desk research, and narrative analysis. The findings of this study help demonstrate how to manage conflict between freedom of expression and religion in Indian society, while exploring concepts of Western secularism and the need to contextualize the right to freedom of expression.
\end{abstract}

Keywords: freedom of expression; Hindu-Muslim; religious-intolerance; secularism; India

\section{Background}

Ancient India is known for its skepticism towards religion and its toleration to opposing views (Sen 2005; Upadhyaya 2009), However, the alarming rise of Hindu religious nationalism and Islamic fundamentalism, and consequently, increasing conflict between freedom of expression and religion, have been well noted by both academic (Thapar 2015) and public intellectuals (Sorabjee 2018; Dhavan 2008).

Conflict between freedom of expression and religion in India is well known. The censoring of books and films by the State, and the victimization of writers, film directors, and academics by Muslim fundamentalist and Hindu religious-nationalist groups are well noted. In this context, the Indian Constitution not only empowers media and free thinkers, but also those who are religiously offended.

Desire among many people to prohibit religiously hurtful speech (or expression) has become a focal point of conflict between religious-fundamentalist groups and free thinkers. Indian Penal Code provisions 298 and 295A have resulted in the harassment of many writers, journalists and academics. In addition, use of violence and fatwa is also being used to suppress freedom of expression by Muslims and Hindu fundamentalist groups.

\section{Hindu Fundamentalism}

The main objective of Hindu religious-nationalists is to establish Hindu rule in India: To spread Hindu values and to defend Hindu society from alien religions, cultures, and ideologies. Among prominent Hindu fundamentalist groups are, R.S.S. (Rashtriya Swayamsevak Sangh), V.H.P. (Vishva Hindu Parishad) and Shiv Sena. Since the early 1980s, these groups, to a certain extent, have been responsible in inciting communal violence against religious minorities in India (Chatry 2012, p. 214). 
These Hindu fundamentalist groups are vehemently against the idea that ethno-religious minorities should have equal rights with Hindus. Within these groups, R.S.S. in particular, ultimately aims to make India a Hindu nation (Hindu rastra) and considers political ideas of secularism, democracy, and Westernization unfit for Indian culture. Hindu fundamentalist forces have become emboldened since the Bhartiya Janta Party (B.J.P.), the Hindu nationalist party, came into power in 2014 and elected Narendra Modi (a full time R.S.S. member) as the Prime Minister of India.

Hindu fundamentalism has succeeded in threatening publishers to withdraw publications, exerted pressure to censor films deemed offensive to their political agenda, and silenced critical voices contesting the Hindu religious myths and legends (Thapar 2015; Sorabjee 2018; Dhavan 2008). The killing of journalist Gauri Lankash ${ }^{1}$ in 2017, who was critical of the right-wing and of Hindu nationalism, and of violence in the wake of the controversial movie, Padmavati, ${ }^{2}$ shows that such fundamentalist forces are restricting free expression by creating a climate of fear.

The fear of the mob is so palpable that even after a court order lifted restrictions on James W. Laine's book on Shivaji, bookshops are still unwilling to stock it (Tripathi 2015). Thus, forces of fundamentalist Hindutva ${ }^{3}$ are posing serious challenges to the freedom of expression and liberal voices in India.

\section{Islamic Fundamentalist}

British rule over India was a setback to the Mughal empire, leading to a loss of power among its elites. Consequently, Muslim backwardness and the political reassertion of Hindus in India, to a certain extent, led to Muslim nationalism (Rodriguez 2017, p. 55). Later, the rise of Deoband (Conservative Islamic seminary) and the Aligarth school played an important role in Islamic nationalism and affirmation of Islamic religious ideas. The idea of 'purifying' Islam and Muslims in India (through vigorous preaching and holy war) was formulated by men like Shariatullah and Syed Ahmad and expressed some of the fears haunting the local Muslims. This generated in India's Muslim elites a preoccupation with the "revival of Islam's lost glory".

The foundations of the Indian National Congress in 1885 and fear of Hindu domination led the establishment of the Muslim League, which demanded a separate state for Muslim-Pakistan. Through the rise of Hindu revivalist movements, Arya Samaj and Braham Samaj crystalized Hindu nationalism and Muslim fundamentalism. After Indian Independence in 1947, Muslims remain backward-economically and politically (Sachar 2006). However, for fundamentalist Muslims, the ideal has remained for an Islamic state and a universal Islamic revolution.

Insurgency in Kashmir and the Babri mosque demolition further alienated Muslims in India. According to Varshney (1992); Pakistan, the Indian state, Hindu nationalism, and Kashmiri Muslim ethno-religious nationalism all contributed to the polarization of the Hindu-Muslim population. As a result, mutual suspicion helped strengthened fundamentalist forces in Muslim society.

Usually, fundamentalist Islamic groups ${ }^{4}$ such as Deoband and All India Muslim Personal Board resort to mob violence, religious and public condemnation, or filing cases in the court if they deem anything to be offensive to their religion. India banned the book Satanic verses in 1988 due to pressure from Muslim political groups. A book by Bangladeshi author Taslima Nasrin ${ }^{5}$, 'Dwikhandita', was also banned in India for offending religious sensibilities of Muslims. Under pressure from Islamic fundamentalists, the Indian government even refused to grant Nasrin citizenship.

\footnotetext{
http://www.theoslotimes.com/article/india\%3A-killing-the-sane-voices-

http:/ /www.bbc.com/news/world-asia-india-42048512.

See (Varshney 1993, pp. 227-61).

http://www.darululoom-deoband.com/english/.

All India Muslim Personal Board offered 500,000 rupees (Approx. USD 7500) for her beheading in March 2007. https:

//en.wikipedia.org/wiki/Taslima_Nasrin.
} 
Shirin Dalvi, editor of an Urdu newspaper, was arrested for printing a controversial cover of French satirical magazine Charlie Hebdo. Dalvi was booked and charged with outraging religious feelings ${ }^{6}$ by insulting its religion with malicious intent under Section 295A of the Indian Penal Code. ${ }^{7}$ Similarly, Hindu Mahasabha activist, Kamlesh Tiwari earned the wrath of Muslims for making derogatory remarks against the Prophet Mohammed. As a result, thousands of Muslims demanded the death penalty for Tiwari. ${ }^{8}$

In the court, Indian Penal Codes (IPC) 298, 295A, 153A have been invoked against free thinkers. ${ }^{9}$ In more informal ways, fatwa, physical violence, and threats have been employed by Islamic fundamentalists. Free thinkers normally face challenges at two levels; either the offended party drags them into the court of law or coerces them with intimidation, physical violence, and social pressure.

However, to deal with the complex and multi-religious nature of Indian society, the Indian government applies a peculiar form of secularism where tension always persists between liberal and conservatives, modern and old, and between religion and rights. Article 19(1)(a) of the Indian Constitution guarantees freedom of speech and expression as a fundamental right. However, According to Article 19(2), freedom of expression is subject to the security of the State, friendly relations with foreign States, public order, decency or morality ... ". The broad phrasing of these limitations gives the state extensive powers to justify curtailments and to unduly restrict freedom of expression (Tripathi 2015, p. 11).

Interestingly, Indian secularism was frowned upon by both radical Muslims and Hindu nationalists. Anti-secularist arguments are embedded in the generic critique of modernity where secularism is associated with the project of modernity, science, and rationality as it mocks the believer for his morality and religiosity (Varshney 1993, p. 245).

This section briefly discusses theories applied in this study.

\section{Secularism and Multiculturalism}

During the first decade of the twentieth century, social orthodoxy in India and anticolonial political space were monopolized by Hindu cultural revivalists. Congress leader Mahatma Gandhi explicitly subordinated the freedoms of individuals to broader cultural and spiritual concerns with the revival of Indian civilization as well as the "sentiments" of religious groups, in line with the emerging discourse of "Indian secularism" (Balsekar 2014). For the sake of managing vast multicultural Indian society and to prevent potential sectarian violence, it has become vital for the newly liberated Indian State to be seen as neutral, thus, 'political neutrality' has become the guiding principle, which to a certain extent, has led to Indian secularism. The Supreme Court of India defines secularism as "more than a passive attitude of religious tolerance; it is a positive concept of equal treatment of all religions (Mahmood 2006, p. 388)".

In the Indian context, some scholars have argued secularism being of Western character; incompatible to indigenous world-views: Deeply insensitive to religious people (Bhargava 1994; Chatterjee 1994). However, Taylor (2011, pp. 36-49) considers secularism as the response of the democratic state to manage diversity, and secular reason is a language that everyone speaks and can argue and be convinced in. India, follow a modified version of secularism (Bhargva refer it as a sort of

6 Blasphemy, which is criminalized by s.295A of the IPC, is defined as expression that is "intended to outrage religious feelings of any class by insulting its religion or religious beliefs".

7 See more at: http://indianexpress.com/article/india/india-others/urdu-newspaper-editor-arrested-over-reprint-ofhebdos-prophet-cartoon/\#sthash.F7q42LWh.dpuf.

8 http://www.thehindu.com/opinion/op-ed/malda-mob-violence-why-so-many-politicians-love-a-riot/article8108145.ece.

9 Section 153A(1)(a) criminalises "words, either spoken or written, or by signs or by visible representations or otherwise, [that] promot $[\mathrm{e}]$ or attemp $[\mathrm{t}]$ to promote, on grounds of religion, race, place of birth, residence, language, caste or community, or any other ground whatsoever, disharmony or feelings of enmity, hatred or ill-will between different religious, racial, language or regional groups or castes or communities. 
Contextual Secularism) to cater its cultural political space; widening broader space for religious affairs within the secular political structure.

Parekh (2006, p. 195) stated that there is a no single model fit for all nations. He suggested to every multicultural society to devise its own appropriate political structure to suits its history, cultural tradition, and range and depth of diversity. In this context, the Indian method of managing religious diversity, to a certain extent, is responsible for the birth and growth of Indian Contextual secularism—conceptually distanced from its Western counterpart and suitable for India's multicultural needs.

Bhargava (1994, p. 3) has argued that complete secularization of society is neither possible nor desirable. Bhargva believe that intermingling of religion and politics is permissible as long as it helps meet their objectives but if any forms of blending defeats their aims, then their amalgamation must be restrained (Ibid). His idea on Contextual secularism shares conceptual proximity with Tariq Modood's moderate secularism. Tariq has advocated for religious accommodation of European Muslim minorities in strict secular states of European nations. Tariq Modood (2007, p. 72) has argued for an accommodative model that respects religion and that goes beyond both toleration and even civic recognition.

Bhargava (1994, p. 9) propagates that a principled distance must be maintained between religion and politics, which could reflect a 'commitment to some version of political neutrality' and the mutual respect between religion and politics.

Nevertheless, the idea of 'principled distance' appears profoundly problematic. John Rawls and Thomas Nagel have argued against principles of state neutrality questioning notions of state impartiality and religious toleration to other areas of moral disagreement (cited in Chatterjee 1994, p. 1773). As Chatterjee (Ibid) commented, in the case of religion, the existence of fundamentally divergent moral values in society would imply there is no rational way in which reasonable people might resolve dispute, and since the state should not arbitrarily favor one set of beliefs over another it must not be asked to intervene in such conflicts.

\section{Public Sphere and Reasoning}

Habermas favors a conception of the public sphere that relies on fair procedures that guide public deliberation, but do not restrict citizens' participation; his conception of the public sphere emphasizes the ideal of equal participation rights in open public discourse (Habermas 2004, pp. 15-18). Habermas (Ibid) calls for self-modernization of religions. While Rawls argues citizens ought to provide public justifications for political positions, Habermas leaves open the types of reasons that can be provided in the informal public sphere (cited in Yates 2007, p. 181).

However, Rawls's idea of 'duty of civility' demands citizens to share the burden of separating their political views from essentially religious beliefs, while holding government officials accountable who violate public reason (Rawls 1997, p. 765). For Rawls, public reason, which establishes norms for democratic discourse, applies to a limited domain but, rather, within a more restricted sphere ... (Cited in Charney 1998, p. 97). The public reason in its strictest form precludes appeals to particular comprehensive moral, religious, or philosophical doctrines in the public sphere (Rawls 1993, pp. 10, 214-18). For Rawls, the free exercise of religion remains a "private" right of individuals (although it is a right most often exercised by individuals as members of various groups). However, Rawls's doctrine prevents religious citizens from having a 'religiously integrated existence' forcing them to make a sharp division between reasons that they link closely in their minds'.

Applying Rawls- and Habermas-concerned theories in the Indian context requires serious conceptual adjustment as they failed to appreciate hugely diverse religious and ethnic values of Asian society. In this context, Parekh (2006, pp. 310-11) expressed that "political deliberations also shall be judged for its moral, epistemological and community-sustaining role since all arguments are articulated and conducted in a particular language, thus theories of political deliberation, such as those of Rawls and Habermas, remain unrealistic". 


\section{Religion and Human Rights}

Relation between the discourse of human rights (particularly freedom of expression) and religion is complex. Witte and Green pointed out (Witte and Green 2011, p. 17) "While human rights norms encourage pluralism and diversity, many religious bodies require orthodoxy and uniformity ... while human rights norms teach freedom of expression and petition, several religions teach duties of silence and submission".

Nevertheless, some religions started to see human rights as natural rights rooted in natural law, and natural law is religiously inspired. Their (values) interchanges have been increased globally and are of the utmost importance to maintain communal harmony in a pluralistic society-particularly in a society where religion is a way of life, and where human rights norms are still at the nascent stage. Religion in India has been a way of life for ages, but human rights as a Western modern legal concept is relatively new. Thus, for the effective management of a multiculturalist pluralistic society, it could be necessary for human rights and religion to be seen as a unified part of the same societal cosmos. An-Naim supports a legal system with a pluralistic mode of interpretation that respects 'the right of the local community to be the living frame of interpretation for its own religion and its normative regime (An-Naim 1995, p. 233-40).

However, Henkin (2000, p. 237) is concerned about how religious fundamentalist movements in different parts of the world are intolerant to other denominations within their own religion as well as with other religions. They either seize or join political power. This is what is happening in India where not only Hindu fundamentalism is in direct conflict with human rights of freedom of expression.

In India, fundamentalism is in direct conflict with the discourse of human rights. Nevertheless, it is undeniable that religion has been, and still is, a formidable force for both political good and political evil, it has fostered benevolence and belligerence, peace and pathos of untold dimensions; the proper response to religious belligerence is not to limit religion to the private sphere, but rather to conform those religious teachings and practices that are most conducive to human rights, democracy and the rule of law (Witte and Green 2011, p. 15).

\section{Theoretical Discussion}

India is a secular democracy. Not in the sense of a strict separation between Church and State as per the Oxford dictionary definition-not connected with religious or spiritual matters. ${ }^{10}$ India, follows a contextualized version of secularism (Bhargva refers to it as contextual Secularism) to cater for its multi-cultural political needs.

\section{Contextual Secularism}

In Indian society, tension always lingers among multi-ethnic, multi-religious, and multi-linguistic communities; thus, in order to respect religious plurality, to control interreligious violence, and to protect communal harmony; the secular Indian state justifies limiting the freedom of expression (Balsekar 2014; Parekh 2006; Bhargava 2006). The dominant justification of the policies and practices of the Indian state were done by appealing to contextual secularism; contextual secularism (Bhargava 1994, p. 25) advocates state-intervention for the sake of substantive values, such as human rights and democracy. It has been applied to manage Hindu-Muslim communal tensions and to maintain religious neutrality.

\section{Indian Contextual Multiculturalism}

India's attempts to manage its cultural diversity and originating tensions have led to the policy of political recognition and the policy of cultural accommodation. It has been argued that at the heart

10 http://www.oxforddictionaries.com/definition/english/secular. 
of the resolution of many ethnic conflicts in India lies a set of so called multicultural state policies (Bhattacharya 2003; Balsekar 2014). Balsekar (2014) has categorized India as a multicultural country which grants extensive group rights and cultural protection to any section of citizens in its constitution. For Parekh, the Indian constitution has well accommodated its diversity and plurality. ${ }^{11}$ Thus, to a certain extent, the Indian government applies a form of contextual multiculturalism.

Multiculturalism is concerned with particular kinds of cases (e.g., involving cultural diversity) characteristic of specific kinds of contexts (e.g., countries containing indigenous or national minorities or experiencing immigration). In addition, the context is relevant in the sense that it determines the kinds of cases to which arguments or theories aim to apply. Parekh (2006, p. 307) noted, "political deliberation is contextual and culturally embedded, it is never wholly based on arguments alone, and no single model of it fits all societies".

\section{Indian Contextual Secular-Multiculturalism}

On the one hand, India follows a 'principled distance' in state-religious affairs (employing contextual secularism), while on the other hand, it seeks to manage religious conflict harmoniously and practice contextual multiculturalism. In line with prior discussion, there is a theoretical framework emerging-through which a complex interaction between state, human rights, and the management of religious diversity and conflict can be approached. This is the concept of Indian contextual secular-multiculturalism.

However, contextualizing the concept of secular-multiculturalism in an Indian context, practically, could tilt the nation towards a theocratic state, which could both limit the role of secular- minded persons in the public sphere, and potentially restrict freedom of expression. The unclear/blurred relationship between State and religion is also an invitation to undue intervention in the private religious affairs of the communities by the State. Particularly by the dominant religious-nationalist groups as it is apparent in the case of Triple Talaq, where Prime Minister Narendra Modi appealed to the Muslim community to do away with Triple Talaq. ${ }^{12}$

Throughout this Study, the author has applied the theoretical framework of contextual secular-multiculturalism. This Conceptual framework is employed to explain how, and why, the Indian State responds to religion-rights conflicts. The following case study and resulting analysis is conducted in line with this conceptual framework.

\section{Background of the Research}

In different ways, many scholars have performed critical investigation into religious-nationalist groups, censorship, and secularism in India (Balsekar 2014; Bhargava 2006; Frøystad 2013). However, there are limited empirical studies conducted within the contextual secular-multiculturalism framework, particularly involving the city of Varanasi.

This study is based on field work in Varanasi, conducted in 2016, as a part of the author's masters thesis. Varanasi, also known as Benares, (Bana ${ }^{-}$ras [bə' na:rəs], or Kashi (Ka ${ }^{-} \mathrm{si}^{-}{ }^{-}{ }^{\prime} \mathrm{ka} / \mathrm{i}$ ], is a North Indian city; ${ }^{13}$ the spiritual capital of India, it is the holiest city in Hinduism, Jainism, and Buddhism and it has gained notoriety for Hindu-Muslim riots.

All interviews were conducted at the university campus in Varanasi. Hindu respondents were master students of political science, mass communication, and social work, whereas Muslim students

11 The Indian Constitution guarantees all religious communities the freedom to manage their own affairs in religion, acquire and manage property, and to establish institutions for religious and charitable purposes (Art.26). The Constitution entitles every section of citizens to conserve their distinct culture, language and script, imposing at the same time on all citizens a fundamental duty "to value and preserve the rich heritage of our composite culture (art. 29 (1) and 51-A (f)) (Constitution of India 2014).

12 https://timesofindia.indiatimes.com/india/triple-talaq-validity-case-all-you-need-to-know/articleshow /60169600.cms.

13 https://en.wikipedia.org/wiki/Varanasi. 
studied Islamic religion at bachelor level. Two universities were consulted for Hindu students' interviews. Seven male students from Kashi Vidya Peeth University and two female students from Arya Mahila Degree College were interviewed. In addition, four Muslim students from Al-Jamia Tus Salafiah (Deemed University) were also interviewed.

Interviews were conducted in Hindi (the local language of respondents and researcher). Before each interview, a brief introduction of current socio-political situation was given to the respondents orally. The main purpose of the interview was to obtain students perceptions related to the conflict between the freedom of expression and religion in India. To note, a sudden rise in intolerance against liberal values, and religious minorities has plagued India since the Hindu nationalist party came into power in $2014 .^{14}$ This fact has influenced respondents' narratives.

\section{Research Methodology}

This research has employed qualitative research methodology tools such as in-depth interviews and semi-structured interviews in order to understand and broaden the scope of understanding of students' world views, thoughts and behavior. Empirical data was derived from the respondent's perception on the conflict between freedom of expression and religious intolerance in the context of fundamentalist Muslim and nationalist Hindu in India.

The focus of interviews was guided by two broad questions: (1) Is Freedom of Expression under jeopardy due to religious intolerance from fundamentalist elements of Hinduism and Islam; and (2) How does a student perceive the conflict between freedom of expression and religious intolerance?

Interview questions implicitly touched on the theoretical foundation of this research (conflict in multicultural society, cultural accommodation, and religious tolerance). Using interviews as research instruments offered student's narratives on the role of freedom of expression and religion in their lives, and their own definitions of terms such as fundamentalism, freedom of expression, intolerance, and secularism. The guide approach was used ensuring the same general area of information is collected from each respondent.

A total of thirteen respondents were interviewed. Respondents were divided in two categories: Four Muslim graduate students and nine Hindu graduate students (including two Hindu female students). Narrative contents were categorized under various themes related to this research. The aim of the narrative interviews was to elicit interviewees' reconstructed accounts of connections between events, and between events and contexts (Bryman 2012, p. 584). Narrative analysis is an approach to the analysis of qualitative data that emphasizes the stories that people employ to account for events.

Grounded theory as a general strategy of qualitative data analysis is applied by putting relevant theory into data. In grounded theory, different levels of coding are recognized (Bryman 2012, p. 568). To make sure concepts fit well with indicators, categories are generated through a constant comparison between indicators and conceptualization, and between examination and organization of the respondents' interviews. This process was continued until theoretical saturation (when data no longer generated new theoretical understanding) was reached.

A thematic analysis is conducted in light of the theories being tested. A theme is a category identified through analysis. It relates to a research question and provides the researcher with a basis of theoretical understanding (Ibid, p. 580). When searching for themes, some points such as repetitions, metaphors and analogies, similarities and differences, and linguistic connections would be taken into account (Ryan and Bernard 2003; cited in Bryman 2012, p. 580). Afterwards, the relationship between emerging data and the hypothesis is explored, which may provide a basis for theoretical understanding, and to fill gaps in knowledge.

To put into action, I have classified similarities, differences and emerging consistent patterns among respondent's interviews. This process is grounded into the concept gained through literature

14 https://timesofindia.indiatimes.com/india/intolerance-on-rise-defend-the-spirit-of-constitution/articleshow/59116622.cms. 
reviews such as secularism, multicultural theory of cultural accommodation, and principles of freedom of expression. During the thematic categorization process, I have synchronized my analysis-gathered through respondent's data and knowledge and gained through literature review-with existing theory.

Due to the small sample size of data, findings of this study are contextual. However, the theoretical inference that emerged would be crucial to wider generalization (Bryman 2012). The researcher, being a Hindu, could have some biases towards Muslim respondents.

This study aims to produce an account of the narratives involved in religious and political processes. Whilst the author is not able to make highly generalized claims, I offer a model for better understanding on the conflictual relation between human rights and religion in an Indian context, and its wider social and political significance which could be expanded.

\section{Narrative Analysis}

Given below is excerpts of themes that emerged following interviews of the 13 students.

\subsection{Thematic Categorization of Hindu Student's Narratives and Analysis}

1 Freedom of Expression has limitations.

Most of the interviewed students felt that the right to freedom of expression cannot be absolute. Some students said that freedom of expression can be restricted to protect communal harmony. Few students believed that faith cannot be ridiculed. In the name of free expression, sacred symbols of Hinduism, such as the cow and the Ganga River cannot be mocked. Most of them believed that religion can only be critiqued to a certain extent.

However, on a critical note, above the thematic narrative, responses implicitly suggest that a religious believer could torment those who believe in secularism and human rights of free expression if their religious sentiments are hurt. Most interesting in the student's narratives was the disregard for secular values and freedom of expression by both Hindu and Muslims students alike. India, though, is not a theocratic state, but respondents still wanted the Indian government to prioritize religion over secularism and human rights. This particular narrative also connects to growing intolerance related to violence currently occurring in Indian society against liberal and secular elements.

2 Justified government censorship on free expression.

Most of the students justified government censorship to protect religious harmony and public order by invoking the multi-religious, multi-ethnic, and multicultural nature of India. Some students believed that government censorship is necessary to counter troublemakers in every religion and to prevent violence. However, few students were skeptical about the government's political motives around censorship. A few students believed that only in very sensitive cases, offensive materials should be censored. Censorship was justified by many students in order to stop troublemakers, to prevent violence, or to maintain social-religious harmony.

Above this thematic narrative, to a certain extent, is support for government action in censoring religious offensive material. This point could be worrying for a secular democratic nation (India in this case) that constitutionally claims to protect fundamental rights of freedom of expression and secular values. In this type of scenario, the possibility to critique religion (even within academia) in public debate is limited due to fear of political correctness and legal sanction. This can tend to suffocate and discourage open discussion in a liberal democratic society. Discouraging open discussion could also lead to violent underground extremism (Binderup 2007).

3 Religious intolerance against freedom of expression is increasing.

The majority of students described a trend of growing intolerance against freedom of expression. Their primary concerns were growing religious Hindu fundamentalism; their political links and strong ideological influence related to the current ruling party (Bhartiya Janta Party-Hindu Nationalist Party). 
Most of them showed concern over physical violence and intimidation by Hindu religious-nationalist groups such as Shiv Sena in Maharashtra, Bajarang Dal and Rastriya Swayamsevak Sangh (RSS) against proponents of free expression, such as writers, social workers, film directors, and others who dared to criticize the Hindu religion. Many students directly related the increasing power of Hindu fundamentalist forces to the political support from the current ruling nationalist party. However, some students believed religious fundamentalism works in the same manner, both in Hindu and Islamic religions alike.

Some students related reasons of religious intolerance with the enforcement of particular ideologies, and efforts to control the lives of citizen. Most students felt there is a climate of fear in the country regarding free expression. Many students were equally concerned about growing Muslim fundamentalism and responses to restrict free expression especially through use of violence by means of fatwa and public intimidation. Nearly all Hindu respondents were alarmed about the shrinking space in Islam for religious critique and blamed it on the intolerant nature of Islam, where dissent on religious matters is strictly restricted and cannot be accepted.

This thematic narrative confirms some of the apprehensions of Indian scholars (Thapar 2015; Dhavan 2008), who have both expressed their deep concern over the government supporting and propagating extreme religious nationalism, particular with the Hindu political party. Intolerance by religious-nationalist groups suggest their desire in encroaching upon government power. Thus, enforcement of certain ideologies by religious-nationalist groups manifest their open desire in power sharing and taking control over the lives of people in a non-democratic manner. This progress is certainly a challenge for a society based on secular-liberal democratic values.

4 Violence, religious enmity, and human rights violations.

Nearly all Hindu students agreed that conflict between free expression and religion results in violence and increased religious enmity. Other significant consequences of this conflict noted by the students were: public riots, curfews, violent demonstrations, and enforcement of religious ideology by fringe elements of religious nationalist groups. The majority of students felt that fundamentalist elements terrify liberal segments of society. Some students were concerned that film directors and writers could be afraid to touch upon religiously sensitive issues; and those who challenge majority views are being pushed outside the public sphere by mainstream media and religious-nationalists.

Many students suggested that this conflict violates many constitutional rights. However, one student believed 'this violence is a natural outcome of the conflict between freedom of expression and religion and a climate of fear is being generated to pressure dissenting narratives. This fact is reflected in the increasing culture of mob violence against authors, film directors, and academics (Tripathi 2015).

5 Communal politics is responsible for conflict.

The majority of students blamed politicians (both Hindu-Muslims) for instigating communal conflicts. One student said that common people have nothing to do with such conflict as they may not be aware of a controversial book or film, and such controversy is blown out of proportion by politicians for political gains-provoking people to induce communal violence. However, few students held politicians responsible for supporting Islamic political groups to appease minorities (in this case Muslims), stoking communal feelings and restricting free expression to those who are critical of Islamic values.

6 Freedom of expression is vital in bringing social and religious reformation.

The majority of students highlighted the importance of freedom of expression in bringing social change and religious reformation in contemporary India. Some of the students suggested freedom of expression played a vital role in creative productions and the intellectual evolution of society. Most of them agreed that critical debate is necessary for the development of society, that free expression 
cannot be restricted unless in rare cases; and that free expression reflects the merits and demerits of society. Thus, without fair criticism of religion, a society cannot progress.

This thematic narrative reflects current and past communal reality in India. Communal politics is ingrained in Indian politics and becomes very much alive before the election period. Politicians, including religious leaders, are known to provoke people to gain political mileage, to strengthen their vote bank, and to increase their socio-political influence. Electoral competition is said to encourage politicians to make illiberal appeals, especially in the context of ethnic politics-this fact is confirmed by Peter deSouza and E. Sridharan (DeSouza and Sridharan 2006; cited in Balsekar 2014). Indeed, power seeking behavior of religious-political leaders is to some extent responsible for communal conflict (Balsekar 2014).

\subsection{Emerging Themes from the Narratives of Muslim Student}

1 Increasing religious intolerance in India.

Most of the students believed that Hindu fundamentalism is escalating. Islam is under attack from such forces, and Hindu political leaders make provocative remarks about the Prophet to gain political mileage. Some students expressed their anger over circulation of religiously sarcastic remarks on social media. Many students reported film star Amir Khan's controversy ${ }^{15}$ as a growing example of the narrowing space for free expression and increasing religious intolerance in India.

Most Muslim students were critical towards religious intolerance. However, intolerance for Muslims refers to verbal attacks from Hindu religious-fundamentalist on their faith. It is a well-known fact that during elections, Hindu political parties make religiously-offensive remarks against Muslims in order to gain political ground.

2 Freedom of expression is restricted.

Nearly all Muslim students said that freedom of expression must not hurt religious sentiments. In their view, the Prophet Muhammad and Islamic holy book Koran are beyond any critical review. Most of the students believed that some Hindu groups are abusing freedom of expression and insulting religious sentiments of Muslims. Many students complained about misuse of freedom of expression by Muslim authors such as Salman Rushdie and Tasleema Nasreen for stigmatizing Islamic values. They believed that freedom of expression shall be used without offending other's religious feelings.

Muslim student's narratives have reflected deep influence of religious values upon student's lives to the extent they are not ready to tolerate any critical review on Prophet Mohammad and on their Islamic holy book, the Koran. Narratives are also a reflection of the fact that some segments of Muslim society are completely guided by fundamental Islamic values-in this case, students' views represent religious-educational culture in Islamic madrasa (school).

Therefore for the Muslim students interviewed, The Prophet and Koran are symbols of their utmost sacred identity; in the multicultural context, identities are shaped by partial recognition or non-recognition by others. In this case, criticizing the Prophet and the Koran is a sort of non-recognition of Muslim identity; in Taylor (2011; cited in Murphy 2012, p. 80) word 'non-recognition or misrecognition can inflict harm since recognition is a vital human need'. The Prophet is a sort of recognition of Islamic identity which must not be criticized because it can inflict harm to the sentiments of all Muslims.

3 Religious sentiments cannot be offended.

All interviewed students believed that religious feelings must not be offended. Most students expressed their unanimity to ban religiously offensive expression in the public sphere. Nearly all

15 http://www.bbc.com/news/world-asia-india-30602809. 
Muslim students privileged freedom of expression over religion. Most students narrated that due to the sensitive nature of religion; religious matters must be analyzed carefully without offending religious sentiments.

4 Justified Government Censorship.

Some students justified government censorship in matters of religious offense. However, few of them complained about discriminatory treatment of government against Muslims. Some students complained about double standards of the government in applying censorship laws [favoring Hindus discriminating Muslims] due to political reasons. In addition, one student expressed 'historical books shall not be banned'.

All students supported government censorship on freedom of expression. However, Muslim narratives reflected a suspicion towards government intentions to censor and pointed to the selective use of laws against minorities to curb their genuine freedom of expression. Muslim student's narratives demonstrated a growing feeling of alienation, sense of hopelessness and loss of trust in the government's ability to protect them from the Hindu majority and offending their religious sentiments.

5 Growing Hindu radicalization.

Many students worried about the increasing power of Hindu fundamentalist political parties which disturb communal harmony and hurt Muslim religious sentiments. Some students expressed their concerns over increasing interference in Islamic affairs and critical stances of Hindu religious-nationalist parties such as Shiv-Sena, Bajrang Dal, and Vishava Hindu Parishad, who publicly make antagonistic statements against Muslims, particularly during national and regional elections. These facts are confirmed in many national, regional and local speeches given by leaders and members from Hindu groups. ${ }^{16}$

One student described the unfair imprisonment of a girl for criticizing a Hindu fundamentalist leader. On her Facebook page, the girl criticized forced shutdown of Mumbai (West Indian city) due to the death of a fundamentalist Hindu leader. ${ }^{17}$ Nearly all students denied the existence of fundamentalist Islam in India. Interestingly, some students viewed themselves as fundamentalists, particularly those who are obedient to their religious laws and expressed that all Muslims must be fundamentalist.

6 Violence is not justified in Islam.

Nearly all Muslim students said there is no place for violence in Islam, and those who resort to violence against freedom of expression do not represent Islam. One student highlighted the importance of Muslim political parties and religious groups working as political pressure groups countering actions of Hindu religious nationalist parties [who defame Islam]. Most students believed that counter-action (against Hindu political party) must be taken within the legal framework; justice must be sought through law. Few students proposed the idea of establishing an interfaith-group, consisting of various religious leaders to monitor and control offensive religious narratives in Indian society.

Due to the increasing global tendency of relating Islam to terrorism, students showed a more cautious approach towards communal conflict and strongly condemned the use of violence. In Hindu narratives, stress was on 'tolerance', whereas Muslim students were anxious to separate the link between Islam and violence.

16 http://indianexpress.com/article/india/india-others/undergo-internal-reform-to-control-population-vhp-appeal-tomuslims/.

17 http://indiatoday.intoday.in/story/2-mumbai-girls-in-jail-for-tweet-against-bal-thackeray/1/229846.html. 
7 Need for Dialogue and Protest within the Rule of Law.

Some students expressed necessity for inter-religious dialogue. Most of them stressed that protest (if religious feelings are offended) must be registered within legal measures. Many students highlighted the need for logical discussion on Islamic principles.

These narratives are in line with Parekh (2006) idea on dialogues among a multicultural society. To deal with multicultural conflict, interfaith dialogues are vital. Not only such dialogues help establish trust and faith among various religious-ethnic groups, but also bring diverse people together.

\section{Personal Observations}

\subsection{Hindu Students}

The Hindu groups of students were primarily master degree students of journalism, mass communication, social work, political science, English literature, and sociology. Due to ongoing political (year 2014-16) debate on issues of intolerance in India, their narratives were crystallized, especially with regards to the statement of actor Amir Khan which provoked strong responses from hardcore religious Hindus. Most of the Hindu students have showed moderate nationalistic tendencies except for one student who had a strong nationalistic-religious tendency.

All of the Hindu students showed keen interest in participating in interviews, except for two students who showed less than average knowledge of the topic concerned. However, most of them were not strict religious practitioners, except from going to temples occasionally. Some of their responses were not influenced with their religious orientation. Most of them were open-minded and had traditional and nationalist orientations.

\subsection{Muslim Students}

Most of the interviewed Muslim students lived in Islamic Madrasa (Islamic university hostel), followed a strict religious discipline and offered five times daily prayer in a mosque located on the University Campus. All of them showed strong religious tendencies and political knowledge about the topic concerned. Most of them, more or less, followed the same line of argument and expressed similar views. It seems their religious orientation provided them with political meaning. Their worldview seems dominated by their religious motivations. They were well informed about national debate on intolerance and the political situation of Muslims and other minorities in India.

In interviewing students, I could sense authoritative voices of the Hindu majority, and an equal feeling of desperation in Muslim minority student's responses and sentiments. Fear of authority and religious hatred created by political leaders and powerlessness characterized their situation. They all voiced their concern over structural and political discrimination. Muslim students lived in close proximity to a mosque. As a student, the Muslim community seemed tightly knitted. Muslim students see fundamentalism as a religious obligation and a compulsion to live by it. For Muslim students, all Muslims are fundamentalist, in the context of upholding belief in the strict religious sense.

In the case of Hindu respondents, fundamentalism was seen as laced with negative traits such as radicalism, terrorism, communal violence and imposition of sharia law. Hindu students, nearly all of them, considered their religion 'a tolerant religion' whereas Islam was associated with intolerance and violence, reflecting stereotyping of the minority. However, many Hindu students highlighted the insecure situation of Hindus in Pakistan and compared this with the relatively better situation of Muslims in India.

All Hindu students spoke Hindi and Muslim students, Hindi mixed with Urdu. Being an insider, the researcher was able to communicate with them fluently in their language, body language was observed, and unspoken words were comprehended. Narratives of students clearly illustrated an ideological divide between Hindu and Muslim students; thus, their perception to researched conflict reflects polarized narratives. Current national debate on issues of intolerance have also played a major role in influencing their ideologies. 


\section{Analysis}

This case study made two facts clear. First, the majority of all, both Hindu and Muslim interviewed students favor religion over human rights and freedom of expression (with concern on increasing religious intolerance and communal violence), as reflected in the themes that emerged in the narrative analysis.

Second, the concept of contextual secularism, to a certain extent, is able to explain researched phenomena. However, findings of this research, due to the small sample size, are applicable only in certain locations and situations.

In the Indian multi-cultural context, the theory of absolute secularism is not feasible. Rather, it needs to be contextualized. This is also empirically confirmed in the thematic analysis of the students' narratives.

Applying the concept of contextual secularism in an Indian context also implicitly infers that freedom of expression has certain limitations due to the multi-religious nature of Indian society. However, it also implies that academia and art must enjoy relatively broader spaces of free expression; that they shall be protected from legal and physical threat from religious groups, and in a general sense, the use of censorship can be applied in press and electronic media, and in public forums in the case of impending communal violence. Nevertheless, in reality, communal politics by the current Hindu nationalist national party has religiously polarized the Indians, supported fringe Hindu radical groups, and increased religious violence and intolerance against freedom of expression and religious minorities. This shows the limitation of Indian secularism.

However, in student narratives, some voices were in favor of religious and social dialogue. Parekh (2006) also asserts a vital need for political dialogue based on society-operative public values. However, such political dialogue requires tolerance and mutual respect. Rawls (1997) also demands citizens - as their moral duty - to apply the idea of toleration in public reasoning. Thus, citizens need to prioritize the public good over his/her personal interest. Habermas argues that secular and religious citizens should share an equal burden in trying to understand one another's reasons in the informal public sphere, thus, both religious and secular citizens ought to share the burden of splitting their identities (cited in Yates 2007).

In both hemispheres, scholars seem polarized over the fundamental conflict between human rights and religion (Witte and Green 2011). However, some prominent Indian scholars justify India's stance on limiting freedom of expression in order to respect religious plurality, to control interreligious violence, and to protect communal harmony (Balsekar 2014; Parekh 2006; Bhargava 2006). Ironically, respect and favor to religious harmony has also resulted in the submission to religious fundamentalist groups, and restrictions of the freedom of expression, as Frøystad (2010) notes. This concern is apparent in the instances of growing Hindu radicalization and religious violence to suppress freedom of expression by Hindu religious-nationalist groups such as RSS, VHP and Bajrang Dal.

Some Western scholars (Rawls 1997; Henkin 2000), who are skeptical about permitting religion in public affairs, argue that religion should support ideas of human rights in the formation of a reasonable society. Rawlsian conceptions of justice allow for a wide range of issues related to secular-religious conflicts. Some believe (e.g., Donnelly 2007) that universal human rights offer considerable space for religious diversity; however, An-Naim (1995) contends that enforcing rights on different cultures without respecting its plurality could be unjust. Similarly, De Sousa Santos (2002) stresses that the universalism of human rights can only be legitimatized when reconceptualized through progressive multiculturalism.

Conceptualizing researched phenomenon through a framework of contextual secular-multiculturalism explains more clearly why states may react in a particular manner, and how and why this concept theoretically plays an important role in determining governments' attitudes towards freedom of expression and religion. On the one hand, Indian secularism allows the state to act as a facilitator by supporting liberal and democratic voices within every religion, while on the other hand, it opens ways for the government to work as an arbiter of free expression and 
could represses moderate voices in the public sphere. It is to be noted, under pressure from Hindu fundamentalism, books such as Mahachaitra by H.S. Shivaprakash, Dharmakarana by P.V. Narayana, and Gandhi Banda by H. Nagaveni have been withdrawn from circulation and university syllabi. India banned the book Satanic Verses in 1988 due to pressure from Muslim political groups. The famous book by Bangladeshi author Taslima Nasrin 'Dwikhandita' was banned in India for offending religious sensibilities of Muslims. Vishwaroopam, a film directed by Kamal Hassan, was banned in cinemas. Muslim groups in Tamil Nadu claimed that the film would hurt Muslim sentiments. Although the film was cleared by the Central Board of Film Certification of India, State of Tamil Nadu gave orders to the theatre owners to not screen the film.

However, the concept of contextual secular-multiculturalism neither privileges freedom of expression nor promotes religion, but tries to create an overlapping consensus with the intention to establish respect and social harmony in a vastly diverse society. In a multicultural society, Parekh (2006) suggests a state is bound to respect and protect human rights of its citizens, minority and majority, fundamentalist and secularist alike. However, to counter intolerance from fundamentalist elements in society, and to maintain socio-religious harmony, the public sphere must be safeguarded.

Thematic narratives have highlighted, in the Indian context, that the State cannot strictly enforce division between state and religion. Thus, to maintain communal harmony and to respect religious sentiments, freedom of expression, to certain extent, could be restricted. Parekh (2006) believes that contextual multiculturalism supports this type (Indian management of dealing diversity) of state practice because it is rooted in local political culture, tradition, and diversity.

The majority of students interviews see the underlying tension between freedom of expression and religion, suggesting there is an inherent conflict between human rights and religion, whereby religious values take priority over liberal values of human rights. In the student's perceptions, religion cannot be criticized while offending religious sentiments; thus, freedom of expression has certain limitations. For, Muslims, The Prophet and Koran are beyond critique and in Hindu religion, the River Ganga and Holy Cow can be critiqued, with some reservations.

Most of the students justified government censorship on free expression. Contextual secularism justifies government action to censor freedom of expression to put public frenzy in the public sphere. In contextual multiculturalism, people's faith and respect for religion and culture is protected (from hate speech) because political deliberation is culturally embedded (Parekh 2006).

Also important is the Indian State's adherence to principled distance, as Bhargava (1994) refers to it, where religion and politics requires neither fusion nor complete disengagement. To maintain political neutrality, the Indian government is usually proactive in protecting the religious sentiments of religious communities (majority and minority alike) as this case study and various examples given in this paper, have demonstrated.

To a certain extent, India's response of toleration of religion over freedom of expression is a product of its unique multicultural situation where dialogues among communities are dialogically constituted and collective principles are generated within a particular moral structure. Since political dialogue occurs within a particular moral structure of a society; it is imperative for states to protect this moral structure for the maintenance of multicultural harmony (Parekh 2006). For Balsekar (2014), censorship is a manifestation of India's particular response to its socio-cultural diversity. This theoretically explains why religiously offending narratives are banned even though it involves a high societal cost. Conversely, this also questions the applicability of human rights such as freedom of expression, in strong traditional communities (Donnelly 1984, p. 417).

The concept of contextual secular-multiculturalism captures the way Indian secularism and multicultural politics are being applied to manage intolerance arising out of the conflict between freedom of expression and religion. This concept was reflected in empirical data. Although India is not completely liberal or absolutely secular, it still qualifies as the largest democracy in the world since it completes all the requirements to be a democratic country (Bhargava 1998). 
Contextual secularism does undermine rights over religion, in this case seen through freedom of expression. Within the scope of Indian contextual secularism, absolute freedom of expression, (as the case Study also showed) is difficult to implement whilst managing religious diversity and harmony. A contextual approach of secular-multiculturalism may not completely eliminate, but might help minimize conflicts between religion and freedom of expression.

\section{Conclusions}

This study has demonstrated that compromises from secular and non-secular citizens are required for a peaceful multicultural society, particularly in an Indian context. In order to accommodate differences and radical point of views, society as well as the state needs to be tolerant; thus, contextual secular-multiculturalism could be an answer in the mitigation of multicultural conflict, particularly between free expression and religion. However, this concept has certain limitations as it still leaves leeway for religious polarization, communal violence and silencing of secular minded people.

The multicultural nature of society, on the one hand requires, formulating policies based on respecting the core principles of religions, on the other, the state needs to guarantee the essentials of freedom of expression, human rights and must provide a safe public sphere-unhindered and unrestricted from religious fanatics. Academics and artists must be able to express themselves freely. They should be free to 'offend, shock or disturb' if it is within their professional ethics. However, the contrary is happening in contemporary India where free expression is under jeopardy due to the fear of Hindu religious nationalist pressure groups.

However, it's difficult to fully appreciate the Western secular model-where negative generalizations about religious minorities are taken for granted, nor Indian secularism-where the balance tips heavily towards public order and religious harmony leaving freedom of expression at the whims of fundamentalist religious groups. Worldwide, there is not one answer to solve conflict between freedom of expression and religion. Answers need to be contextualized in a multicultural society.

Funding: This research was partially funded by Fritt Ord.

Conflicts of Interest: The author declares no conflicts of interest.

\section{References}

An-Naim, Abdullahi Ahmed. 1995. Towards an Islamic Hermeneutics for Human Rights. In Human Rights and Religious Values, an Uneasy Relationship? Edited by Jerald D. Gort and Abdullah A. An-Naim. Grand Rapids: Wm. B. Eerdumans, pp. 229-42.

Balsekar, Ameya. 2014. Seeking Offense: Censorship as Strategy in Indian Party Politics. Comparative Politics 46: 191-208. [CrossRef]

Bhattacharya, Harihar. 2003. Multiculturalism in Contemporary India. IJMS: International Journal on Multicultural Societies 5: 148-61.

Bhargava, Rajeev. 1994. What is Secularism For? Economic and Political Weekly, July 9.

Bhargava, Rajeev. 1998. What is Secularism For? In Secularism and Its Critic. Delhi: Oxford University Press.

Bhargava, Rajeev. 2006. The Future of Secularism. New Delhi: Oxford University Press.

Binderup, Lars. 2007. Global Freedom of Speech. TRAMES 11: 403-18.

DeSouza, Peter Ronald, and E. Sridharan, eds. 2006. India's Political Parties. New Delhi: Sage Publications. Bryman, Alan. 2012. Social Research Methods, 4th ed. Oxford: Oxford University Press.

Charney, Evan. 1998. Political Liberalism, Deliberative Democracy, and the Public Sphere. The American Political Science Review 92: 97-110. [CrossRef]

Chatry, Kailash Kumar. 2012. Understanding the Religious Nature of Terrorism in India: Four Case Studies with an Analysis for Proposal and Resolution. Ph.D. thesis, University of Birmingham, Birmingham, UK. 
Chatterjee, Partha. 1994. Secularism and Toleration. Economic and Political Weekly, July 9.

Constitution of India. 2014. Available online: https:/ /india.gov.in/my-government/constitution-india (accessed on 10 January 2015).

De Sousa Santos, Boaventura. 2002. Towards a Multicultural Conception of Human Rights. In Berta (org.), Moral Imperialism: A Critical Anthology. Edited by Berta Esperanza Hernandez-Truyol. New York: New York University Press, pp. 39-60.

Dhavan, Rajeev. 2008. Publish and Be Damned: Censorship and Intolerance in India. New Delhi: Tulika Books.

Donnelly, Jack. 1984. Cultural Relativism and Universal Human Rights. Human Rights Quarterly 6: 400. [CrossRef] Donnelly, Jack. 2007. The Relative Universality of Human Rights. Human Rights Quarterly 29: 281-306. [CrossRef]

Frøystad, Kathinka. 2010. A Fine Balance Censoring for Respect and Social Harmony. In Demokrati på Indisk: Balansekunst: Mellomytringsfrihet og harmonibegrunnet (selv)sensur. Edited by Engelsen Ruud and Geir Heierstad. Oslo: Unipub.

Frøystad, Kathinka. 2013. Cosmopolitanism or Iatrogenesis? Reflections on Religious Plurality, Censorship and Disciplinary Orientations. In Navigating Social Exclusion and Inclusion in Contemporary India and Beyond Structures, Agents, Practices. Edited by Uwe Skoda, Kenneth Bo Nielsen and Marianne Qvortrup Fibiger. New York: Anthem Press.

Habermas, Jürgen. 2004. Religious Tolerance: The Pacemaker for Cultural Rights. Philosophy 79: 5-18. [CrossRef]

Henkin, Louis. 2000. Religion, Religions, and Human Rights. Journal of Religious Ethics 26: 229-39.

Mahmood, Tahir. 2006. Religion, Law and Judiciary in Modern India. BYU Law Review. Available online: http:/ / digitalcommons.law.byu.edu/lawreview/vol2006/iss3/ 6 (accessed on 6 September 2015).

Modood, Tariq. 2007. Liberal Citizenship and Secularism, In Multiculturalism A Civic Idea. Cambridge: Polity Press.

Murphy, Michael. 2012. Multiculturalism: A Critical Introduction, 1st ed. Abingdon: Routledge.

Parekh, Bhikhu. 2006. Rethinking Multiculturalism Cultural Diversity and Political Theory, 2nd ed. New York: Palgrave Macmillian.

Rawls, John. 1993. Political Liberalism. New York: Columbia University Press.

Rawls, John. 1997. The Idea of Public Reason Revisited. The University of Chicago Law Review 64: $765-807$. [CrossRef]

Ryan, Gery W., and H. Russell Bernard. 2003. Techniques to Identify Themes. Field Methods 15: 85-109. [CrossRef]

Rodriguez, Enrique. 2017. The origins of Muslim nationalism in British India. Journal of Arts E Humanities 6: 55-65.

Sachar, Rajindar. 2006. Prime Minister's High Level Committee for Preparation for Social, Economic and Educational Status of the Muslim Community of India. Available online: http:/ / mhrd.gov.in/sites/upload_ files/mhrd/files/sachar_comm.pdf (accessed on 10 April 2018).

Sen, Amartya. 2005. The Argumentative Indian: Writings on Indian History, Culture and Identity. London: Allen Lane.

Sorabjee, Soli J. 2018. The Limits of Freedom of Expression. Available online: http:/ /indianexpress.com/article/ opinion/columns/sedition-law-constitution-law-freedom-of-speech-5044091/ (accessed on 28 April 2018).

Taylor, Charles. 2011. Why we need Radical Redefinition of Secularism. In The Power of Religion in Public Sphere. Edited by Eduardo Mendieta and Jonathan VanAntwerpen. New York: Columbia University Press.

Thapar, Romila. 2015. The Public Intellectuals in India. New Delhi: Aleph Book Company.

Tripathi, S. 2015. Fear of Mob. In Imposing Silence, The Use of India's Laws to Suppress Free Speech. A Joint Research Project by the International Human Rights Program (IHRP) at the University of Toronto, and PEN Canada. Toronto: University of Toronto.

Upadhyaya, Priyankar. 2009. Peace and Conflict: Reflections on Indian Thinking. Strategic Analysis 33: 71-83. [CrossRef]

Varshney, Ashutosh. 1992. Three Compromised Nationalisms: Why Kashmir has been a Problem. In Perspectives on Kashmir: The Roots of Conflict in South Asia. Edited by Raju G. C. Thomas. Boulder: Westview Press, vol. 52, pp. 768-69.

Varshney, Ashutosh. 1993. Contested Meanings: India's National Identity, Hindu Nationalism, and the Politics of Anxiety. In Reconstructing Nations and States. Summer 1993 issue, Volume 122, pp. 227-61. 
Witte, John, Jr., and M. Christian Green. 2011. Religion and Human Rights: An Introduction. New York: Oxford University Press.

Yates, Melissa. 2007. Rawls and Habermas on the religion in the public sphere. Philosophy and Social Criticism 33: 880-89. [CrossRef] 